\title{
PERMEABILITY OF CAPILLARIES TO PLASMA LIPOIDS
}

\author{
By EVELYN B. MAN AND JOHN P. PETERS \\ (From the Department of Internal Medicine, Yale University School of Medicine, \\ New Haven)
}

(Received for publication June 19, 1933)

It has been rather generally assumed, chiefly because normal urine is practically free from lipoids $(9,10,11)$ that the capillaries are impermeable to plasma lipoids. However, no serious attempts seem to have been made to test this assumption, in spite of its important bearing on the question of plasma colloid osmotic pressure. In order to determine whether lipoids diffuse through the capillaries without simultaneous migration of proteins, two types of experiments have been conducted. 1. Serum lipoids of normal individuals have been measured before and after the volume of the blood has been decreased, by a procedure which has been employed by Thompson, Thompson and Dailey (25), Krogh, Landis and Turner (13) and Ni and Rehberg (19). They demonstrated that if a normal person stands absolutely still for about half an hour the blood volume decreases and the serum proteins increase by about 10 per cent because there is transudation into the tissues of the lower extremities of a protein-free ultrafiltrate of blood plasma. 2. Besides, body fluids have been analyzed for lipoids and proteins.

\section{METHODS AND MATERIALS}

The blood serum of five normal persons was analyzed for proteins, total fatty acids, lipoid phosphorus and cholesterol after they had reclined for half an hour and again after they had stood still for half an hour. All the experiments except one were performed before breakfast. Blood was drawn from the antecubital vein with a minimum of stasis under oil. In all cases except that of P.L. the second blood sample was taken while the subject was standing. In the second group of experiments, the protein and lipoid contents of ascitic, pericardial and pleural fluids were measured. Blood and fluids were collected simultaneously, in most instances before breakfast. All fluids were centrifuged to remove cells and fibrin clot from the aqueous suspension. Proteins were determined by Howe's modification of the Kjeldahl method (5), total fatty acids by the Man and Gildea (16) modification of the Stoddard and Drury technique, cholesterol by a gravimetric digitonin method (17), lipoid phosphorus by a modification of the Fiske and Subbarow method (17). 


\section{RESULTS OF STANDING EXPERIMENTS}

In Table I under each constituent the paired figures in the first

TABLE I

Standing experiments

\begin{tabular}{|c|c|c|c|c|c|c|c|c|c|c|}
\hline \multirow[t]{2}{*}{ Subject } & Date & & \multicolumn{2}{|c|}{ Lipoid $\mathbf{P}$} & \multicolumn{2}{|c|}{$\begin{array}{l}\text { Fatty acids, } \\
\text { "from titer" }\end{array}$} & \multicolumn{2}{|c|}{ Cholesterol } & \multicolumn{2}{|c|}{ Proteins } \\
\hline & & & $\begin{array}{c}\text { mgm. } \\
\text { per } \\
\text { cent }\end{array}$ & $\begin{array}{l}\text { change } \\
\text { per cent }\end{array}$ & m. Eq. & $\begin{array}{l}\text { change } \\
\text { per cent }\end{array}$ & $\begin{array}{c}\text { mgm. } \\
\text { per } \\
\text { cent }\end{array}$ & $\begin{array}{l}\text { change } \\
\text { per cent }\end{array}$ & $\begin{array}{l}\text { grams } \\
\text { per } \\
\text { cent }\end{array}$ & $\begin{array}{l}\text { change } \\
\text { per cent }\end{array}$ \\
\hline P.L. & January 11,1933 & $\begin{array}{l}\text { Before } \\
\text { After }\end{array}$ & $\begin{array}{l}8.4 \\
9.8\end{array}$ & 116.5 & $\begin{array}{l}12.2 \\
14.3\end{array}$ & 116.5 & $\begin{array}{l}199 \\
235\end{array}$ & 118.1 & $\begin{array}{l}6.39 \\
7.47\end{array}$ & 116.8 \\
\hline J.H. & January 23,1933 & $\begin{array}{l}\text { Before } \\
\text { After }\end{array}$ & $\begin{array}{l}9.0 \\
9.6\end{array}$ & 107.2 & $\begin{array}{l}11.6 \\
13.1\end{array}$ & 113.2 & $\begin{array}{l}205 \\
226\end{array}$ & 110.3 & $\begin{array}{l}7.05 \\
7.84\end{array}$ & 111.2 \\
\hline E.M. & January 3,1933 & $\begin{array}{l}\text { Before } \\
\text { After }\end{array}$ & $\begin{array}{r}8.9 \\
10.0\end{array}$ & 112.6 & $\begin{array}{l}11.7 \\
13.2\end{array}$ & 113.5 & $\begin{array}{l}223 \\
246\end{array}$ & 110.2 & $\begin{array}{l}6.94 \\
7.83\end{array}$ & 112.8 \\
\hline E.M. & February $17,1933^{*}$ & $\begin{array}{l}\text { Before } \\
\text { After }\end{array}$ & $\begin{array}{r}9.9 \\
10.8\end{array}$ & 108.6 & $\begin{array}{l}12.6 \\
14.0\end{array}$ & 111.3 & $\begin{array}{l}209 \\
231\end{array}$ & 110.5 & $\begin{array}{l}7.00 \\
7.91\end{array}$ & 113.0 \\
\hline C.R. & January 28,1933 & $\begin{array}{l}\text { Before } \\
\text { After }\end{array}$ & $\begin{array}{l}10.4 \\
10.7\end{array}$ & 102.1 & $\begin{array}{l}16.2 \\
16.0\end{array}$ & 98.8 & $\begin{array}{l}229 \\
260\end{array}$ & 113.5 & $\begin{array}{l}6.33 \\
6.99\end{array}$ & 110.5 \\
\hline C.R. & February 28, 1933 & $\begin{array}{l}\text { Before } \\
\text { After }\end{array}$ & $\begin{array}{r}9.7 \\
10.2\end{array}$ & 105.5 & $\begin{array}{l}12.2 \\
13.5\end{array}$ & 110.7 & & & $\begin{array}{l}6.31 \\
7.10\end{array}$ & 112.6 \\
\hline T.K. & February 1,1933 & $\begin{array}{l}\text { Before } \\
\text { After }\end{array}$ & $\begin{array}{l}8.4 \\
9.6\end{array}$ & 114.1 & $\begin{array}{r}9.9 \\
11.7\end{array}$ & 118.6 & $\begin{array}{l}168 \\
183\end{array}$ & 109.0 & $\begin{array}{l}6.52 \\
7.27\end{array}$ & 111.4 \\
\hline
\end{tabular}

* Second blood taken four and one quarter hours after a breakfast which contained approximately 19 grams of fat.

columns represent the values observed before and after standing, the single figures in the second columns the degree to which the given substance in the serum was concentrated. The significance of "fatty acids from titer" is discussed more fully in the article describing the Man and Gildea modification of the Stoddard and Drury method (16). They found that saponification with potassium hydroxide as in the blood serum method, yielded only 82 per cent of the theoretical fatty acids from reprecipitated Pfanstiehl "pure" lecithin. Consequently, in order to calculate "total fatty acids," there was added to the "fatty acids from titer" 18 per cent of the phospholipoid fatty acid estimated on the assumption that two equivalent weights of fatty acid unite with one combining weight of phosphorus in lecithin and cephalin. Non-phospholipoid fatty acids may be calculated by subtracting from the "total fatty acids" the phospholipoid fatty acids estimated from the serum lipoid phosphorus content. Values for "fatty acids from titer" have been presented here rather than those for non-phospholipoid fatty acids 
because it is recognized that these calculations may introduce a considerable error if the analytical errors of the two methods are cumulative, and because neither the exact chemical composition of phosphatides, nor the proportions of different phosphatides present in serum are known.

Cholesterol, without any exceptions, increased on standing in the same proportion as did the serum proteins, an indication that it is not diffusible. Fatty acids and lipoid phosphorus in 5 of the 7 experiments (P.L., J.H., E.M., January 1 and February 17, and C.R., February 28) increased in the same proportions as the proteins. On the other hand, in the serum of T.K. these constituents increased more than the proteins, and in the serum of C.R. on January 28 they did not change. These divergent responses may be explained by the assumption that the metabolism of fat of these subjects was not in a state of equilibrium. The change in T.K.'s blood sugar, from $76 \mathrm{mgm}$. per cent to 85 after standing, suggests that the metabolism of carbohydrate was not uniform throughout the experiment. In contrast to the normal serum fatty acids in the first blood samples of P.L., J.H., and E.M., the fatty acids both of C.R. on January 28 and of T.K. were at the extremes of the normal range of serum lipoids. C.R.'s total fatty acids on January 28 were the highest of 20 normal subjects and were appreciably greater than they were on February 28. After standing, his fatty acids and phospholipoids did not increase. T.K.'s serum fatty acids, on the other hand, which were among the lowest of the normal values, increased proportionately more than his proteins. From these data it may be inferred, though it is not proven, that C.R. on January 28 was utilizing fat derived from his blood stream, while T.K. was mobilizing fat into his blood stream. An attempt was made to test this hypothesis by carrying out a similar standing experiment on a subject after a meal containing fat. However, the results of the experiment on E.M. on February 17 did not differ from those secured in the postabsorptive state, owing, perhaps, to the fact that too little fat was given.

In these experiments, then, cholesterol without exception, phosphatides and compounds of fatty acids in five of seven instances, behaved like non-diffusible serum proteins.

\section{Comparisons of transudates and serum}

Data concerning the lipoid content of transudates are presented graphically in the three figures. In Figure 1 the protein contents of ascitic, pericardial and pleural fluids are plotted on the ordinate, cholesterol content on the abscissa. The column above each point, at the top of the figure, represents the concentration of cholesterol in the blood serum. The scale for serum cholesterol is $1 / 25$ of that for transudate cholesterol. Irregular variations in the lengths of the columns show that the amounts of cholesterol in the fluid bear no direct relation to the 


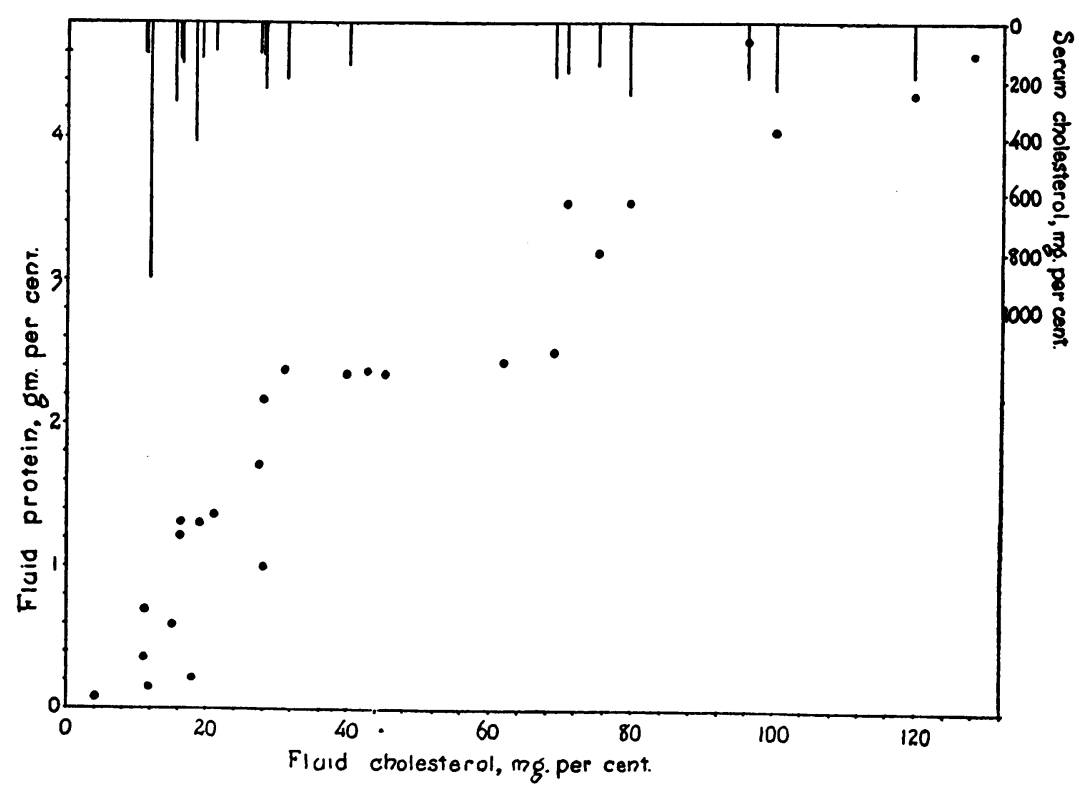

Fig. 1. Comparison of Cholesterol and Protein in Transudates

The vertical lines above indicate the concentrations of cholesterol in the sera of the patients from whom the transudates were secured.

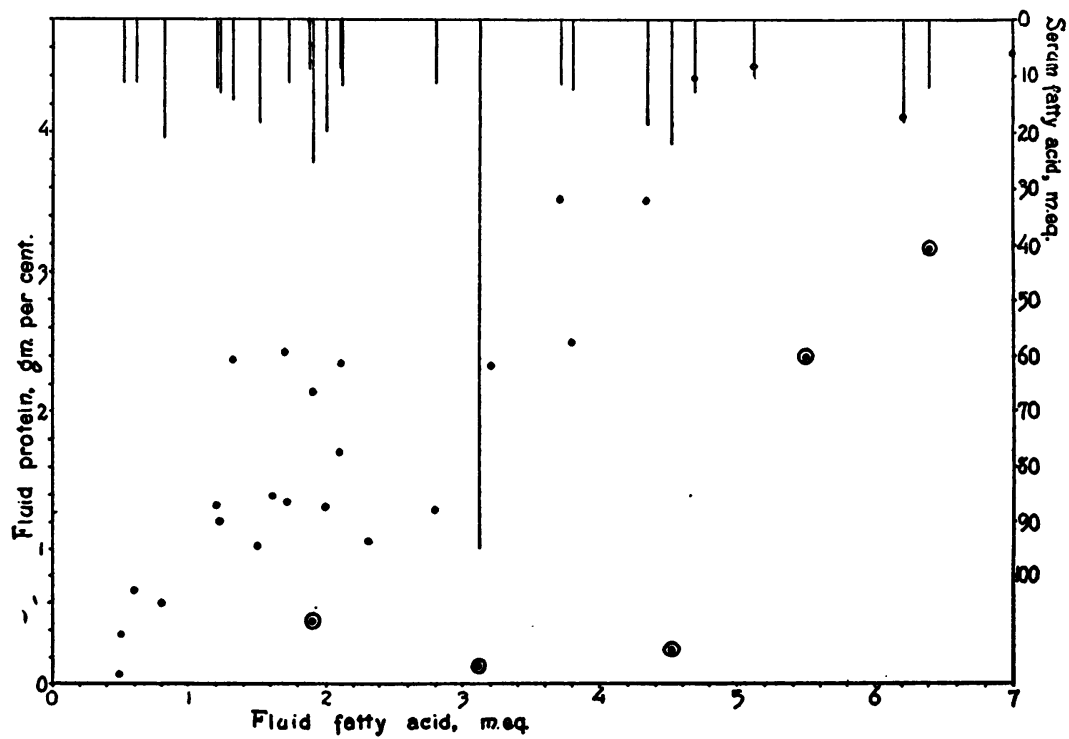

Fig. 2. Comparison of Fatty Acid and Protein in Transudates

The vertical lines above indicate the concentrations of fatty acids in the sera of the patients from whom the transudates were secured. The points surrounded by circles are from patients whose sera contained little protein in proportion to fatty acids. 
concentrations of cholesterol in the serum. There is an obvious tendency for variations of protein and cholesterol contents of fluids to parallel one another.

The arrangement of Figure 2 is similar to that of Figure 1, except that fatty acids from titer are plotted on the abscissa. As was the case with cholesterol, no correlation is evident between the concentrations of fatty acids in sera and transudates. A definite proportion exists between the protein and lipoid contents of the fluids except in those instances which are marked by circles.

If the normal capillary wall is impermeable to lipoids and protein, injury, which increases its permeability, will permit the passage of both lipoids and proteins. The quantities of these substances which actually escape from the vessels will depend not only upon the degree of permeability to the individual components, but also upon the concentrations of these components in the serum. It has already been pointed out that the influence of the latter factor is not demonstrable in the data as a whole. It does, however, become evident in the points surrounded by circles, which represent instances when the protein in the serum was low in proportion to the lipoids. It is especially striking in the lowest of these points. In this instance the serum proteins were reduced to half the normal concentration, while the fatty acids were increased to about nine times the normal. Under these circumstances the lipoid concentration in the fluid might be expected to be, as it proved to be, higher in relation to the protein concentration than it was in the other observations in which the proportions of lipoid and protein in the serum were more nearly normal.

In Figure 3, in which lipoid phosphorus and protein are compared, there is the same lack of correlation between the concentrations of the former in serum and fluid and the same direct relationship between transudate phosphatides and proteins, with one exception marked with a cross. The significance of this exception must be discounted because the peritoneal fluid, taken at autopsy from a patient with peritonitis, was semi-purulent. Some of the lipoid phosphorus may, therefore, have come from pus cells and bacteria.

\section{DISCUSSION}

It is obvious that the distribution of lipoids to the tissues by the blood stream must involve their passage through the capillary walls, in spite of the demonstrated impermeability of the latter. These experiments throw no light on the means by which this transportation is effected; whether the character of the lipoids is altered $(3,4,22,23,24)$, or whether the impermeability of the capillaries is merely a facultative characteristic. In most of the standing experiments, during the half hour period, an equilibrium appears to have been reached and main. 


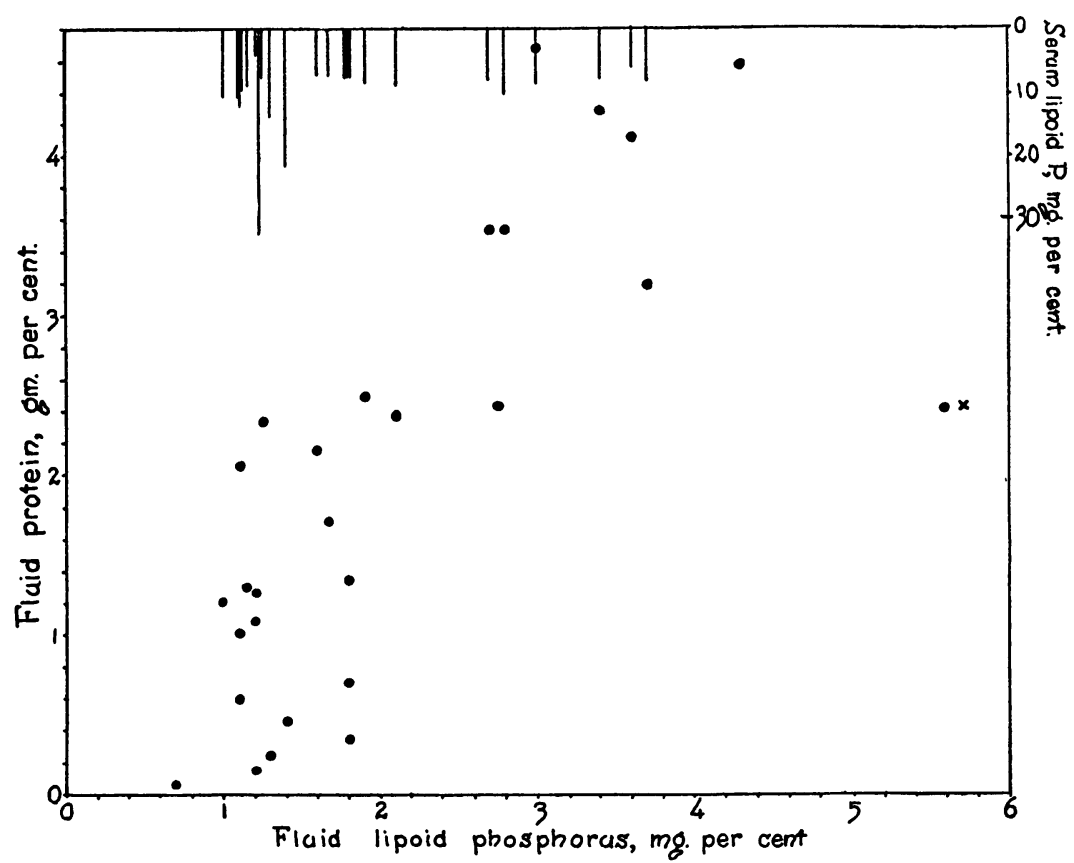

Fig. 3. Comparison of Lipoid Phosphorus and Protein in Transudates

The vertical lines above indicate the concentrations of fatty acids in the sera of the patients from whom the transudates were secured. The point marked by a cross represents peritoneal fluid secured postmortem from a patient with peritonitis.

tained, in which the concentration of all lipoids, like that of proteins, was influenced only by the hemoconcentration that resulted from the loss of serum ultrafiltrate to the tissues. In two cases fatty acids and phospholipoids seem to have been simultaneously affected by some other influence, presumably connected with the metabolism of fat. That cholesterol was not similarly involved is only one more addition to the great body of evidence that this lipoid fraction is not directly concerned with fat metabolism. The problem of the exchange of lipoids between blood stream and tissue cells becomes even more mysterious when, from the studies of transudates, it becomes apparent how little lipoid material $(8,14)$ gains access through normally permeable vessels to the interstitial fluids, which presumably serve as the medium of exchange between blood and cells.

The association between lipoids and proteins $(2,12,15,18,20,21,29)$ in both types of experiment might suggest that the lipoids are restrained by combination with proteins. Such a deduction is not, however, obligatory. Such combinations may exist and the proteins may act as vehicles for a certain amount of lipoid material. In the case already 
referred to in which protein was reduced and lipoid greatly increased in the serum, a greater amount of lipoid might have been expected in the transudates if it had been restrained from traversing the walls of the vessels only by its combination with protein.

The exact correlation between the changes of cholesterol and protein in these experiments has a bearing on the nature of the interstitial fluids. Thompson, Thompson and Dailey (25), comparing the volume of the blood, determined by the dye method, with the concentration of proteins in the serum, concluded that the fluid which passed from the blood stream into the tissues of the leg contained no protein. Waterfield (27), in similar experiments, in which he measured the blood volume by the carbon monoxide instead of the dye method, believed that he detected evidence of serum protein loss probably involving only the albumin fraction. More recently Youmans, Wells, Donley and Miller (30) have shown that the protein fractions and total proteins of the serum are all proportionately affected by the hemoconcentration. To these cholesterol can now be added. It is hardly conceivable that if the capillary membranes, under the conditions of these experiments, were permeable enough to permit appreciable quantities of protein to pass out, both fractions and cholesterol would all escape in exactly the same proportions. Certainly such an association is entirely incompatible with Waterfield's conclusions. Krogh, Landis and Turner (13) also found no evidence of loss of serum protein when transudation was induced in the arm by venous obstruction. It becomes harder in the light of these experiments to believe that capillary filtrates produced by venous stasis can contain as much protein as Drinker and Field (6) believe.

If the capillary walls are impermeable to lipoids, the latter may exert an appreciable colloid osmotic pressure in the blood stream and, on this account, have some influence upon the exchange of fluids in the body. Indirect evidence of various kinds indicates that the osmotic pressure of the lipoids is extremely small $(1,7,28)$; but more exact data on the subject are greatly to be desired.

\section{CONCLUSIONS}

By standing experiments aimed to produce physiological transudation of fluid from the blood stream, and by comparisons of proteins and lipoids in serum and in pathological transudates, evidence has been adduced which indicates that the capillary walls are ordinarily impermeable not only to proteins but also to cholesterol, phosphatides, and compounds of saturated and slightly unsaturated fatty acids.

\section{BIBLIOGRAPHY}

1. Adair, G. S., and Robinson, M. E., Biochem. J., 1930, xxiv, 1864. The Analysis of the Osmotic Pressures of the Serum Proteins and the Molecular Weights of Albumins and Globulins. 
2. Bennhold, H., Klin. Wchnschr., 1932, xi, 2057. Über Transportprobleme im tierischen Organismus.

3. Berend, N., Biochem. Ztschr., 1930, ccxxix, 323. Der Einfluss verschiedener Nahrungsmittel auf die Menge der vierfach ungesättigten Säuren im Blute.

4. Berend, N., Biochem. Ztschr., 1932, ccxlvi, 117. Über die Rolle der stark ungesättigten Fettsäuren im Organismus.

5. Bruckman, F. S., D'Esopo, L. M., and Peters, J. P., J. Clin. Invest., 1930, viii, 577. The Plasma Proteins in Relation to Blood Hydration. IV. Malnutrition and the Serum Proteins.

6. Drinker, C. K., and Field, M. E., Lymphatics, Lymph and Tissue Fluid. Williams and Wilkins Company, 1933, Baltimore.

7. Fishberg, E. H., J. Biol. Chem., 1929, lxxxi, 205. The Relations of the Serum Proteins and Lipids to the Osmotic Pressure.

8. Foord, A. G., Youngberg, G. E., and Wetmore, V., J. Lab. and Clin. Med., 1929, xiv, 417. The Chemistry and Cytology of Serous Fluids.

9. Gáal, A. M., Ztschr. f. d. ges. exp. Med., 1930, lxxi, 690. Untersuchungen über Cholesterinstoff wechsel.

10. Gardner, J. A., J. Laryng. and Otol., 1932, xlvii, 395. Cholesterol Metabolism.

11. Gardner, J. A., and Gainsborough, H., Biochem. J., 1925, xix, 667. Cholesterol Secretion in the Urine. Part I.

12. Gardner, J. A., and Gainsborough, H., Biochem. J., 1927, xxi, 141. Studies on the Cholesterol Content of Normal Human Plasma. Part II. The Attraction of the Proteins of Plasma for Sterols.

13. Krogh, A., Landis, E. M., and Turner, A. H., J. Clin. Invest., 1932, xi, 63. The Movement of Fluid Through the Human Capillary Wall in Relation to Venous Pressure and to the Colloid Osmotic Pressure of the Blood.

14. Macheboeuf, M. A., and Fethke, N., Bull. Soc. chim. biol., 1932, xiv, 507. Recherches sur les lipides et les protéides des liquides d'épanchements non purulents des séreuses.

15. Macheboeuf, M. A., and Sandor, G., Bull. Soc. chim. biol., 1931, xiii, 745. Recherches sur la nature et la stabilité des liaisons protéides-lipides du sérum sanguin. Étude de l'extraction des lipides par l'éther en presence d'alcool.

16. Man, E. B., and Gildea, E. F., J. Biol. Chem., 1932, xcix, $43 . \quad$ A Modification of the Stoddard and Drury Titrimetric Method for the Determination of the Fatty Acids in Blood Serum.

17. Man, E. B., and Peters, J. P., J. Biol. Chem., 1933 (in press). Gravimetric Determination of Serum Cholesterol Adapted to the Man and Gildea Fatty Acid Method, with a Note on the Estimation of Lipoid Phosphorus.

18. Merklen, Pr., Le Breton, E., and Adnot, A., Compt. rend. Acad. d. sc., 1931, cxcii, 1053. Influence des lipides du sérum sur la précipitation et le dosage des globulines sériques.

19. Ni, Tsang-G., and Rehberg, P. B., J. Physiol., 1931, lxxi, 331. On the Influence of Posture on Kidney Function.

20. Reiner, L., Biochem. Ztschr., 1927, cxci, 158. Zur Kenntnis des Serumglobulins.

21. Sörensen, S. P. L., Compt. rend. d. trav. du lab. Carlsberg, 1930, xviii, 1. The Constitution of Soluble Proteins.

22. Tangl, H., Biochem. Ztschr., 1930, ccxxvi, 180. Mikromethode zur Bestimmung von vierfach ungesättigten Fettsäuren. 
23. Tangl, H., and Berend, N., Biochem. Ztschr., 1930, ccxx, 234. Die Fettresorption durch die Desaturation der Fettsäuren.

24. Tangl, H., and Berend, N., Biochem. Ztschr., 1931, ccxxxii, 181 . Weitere Versuche über die Fettresorption durch die Desaturation der Fettsäuren.

25. Thompson, W. O., Thompson, P. K., and Dailey, M. E., J. Clin. Invest., 1927-28, v, 573. The Effect of Posture upon the Composition and Volume of the Blood in Man.

26. Turner, M. E., and Gibson, R. B., J. Clin. Invest., 1932, xi, 735. A Study of the Protein-lipid Combinations in Blood and Body Fluids. I. Normal Human and Dog Plasma and Horse Serum.

27. Waterfield, R. L., J. Physiol., 1931, lxxii, 110. The Effects of Posture on the Circulating Blood Volume.

28. Wells, H. S., Am. J. Physiol., 1932, ci, 409. Some Criteria of Accuracy for the Measurement of the Osmotic Pressure of Colloids in Biological Fluids.

29. Went, S., and Goreczky, L., Biochem. Ztschr., 1931, ccxxxix, 441. Die Verteilung der Serumphosphatide und des Cholesterins in durch Filtration durch grossporige Kollodiumfilter gewonnenen Serumultrafiltraten.

30. Youmans, J. B., Wells, H. S., Donley, D., and Miller, D. G., J. Clin. Invest., Proc., 1933, xii, 965. The Effects of Posture (Standing) on the Serum Protein Concentration and Colloid Osmotic Pressure of Blood from the Foot in Relation to the Formation of Edema. 